\title{
Treatment of hepatitis $C$ genotype 1 patients with severe fibrosis or compensated cirrhosis: the telaprevir early access program in patients from Romania
}

\author{
Adrian Streinu-Cercel ${ }^{1,2^{*}}$, Anca Victorița Trifan ${ }^{3,4}$, Florin Alexandru Căruntu ${ }^{1,2}$, Ioan Sporea ${ }^{5}$, \\ Liliana Simona Gheorghe ${ }^{1,6}$, Manuela Curescu, ${ }^{5}$, Mihai Mircea Diculescu ${ }^{1,6}$, Mihai Voiculescu, ${ }^{1,6}$, Oliviu Pascu , \\ Isabelle Lonjon-Domanec ${ }^{8}$, Andrew Martin Hill ${ }^{9}$, Sorin Rugină ${ }^{10,11}$
}

From The 9th Edition of the Scientific Days of the National Institute for Infectious Diseases Prof Dr Matei Bals Bucharest, Romania. 23-25 October 2013

\section{Background}

HEP3002 is an ongoing, open-label, early access program of telaprevir in 16 countries, for patients with genotype 1 hepatitis $\mathrm{C}$ with severe fibrosis or compensated cirrhosis. This interim analysis is of 16 week data from the 209 patients from Romania.

\section{Methods}

Patients were treated with telaprevir in combination with peginterferon alfa and ribavirin (PR) for 12 weeks, followed by PR for 12 or 36 weeks. Severe fibrosis/cirrhosis was defined by liver biopsy (Metavir F3-4 or Ishak 3-6) or noninvasive tests. Platelet count $>90,000 / \mathrm{cmm}$ was required at entry. HCV RNA was evaluated at baseline and Weeks 4 and 12 of treatment. Virological response was defined as serum HCV RNA not detected, for the Intent to Treat (ITT) population.

\section{Results}

Mean age was 52 years; $47 \%$ were male and $100 \%$ Caucasian, $59 \%$ had HCV RNA levels $\geq 800,000 \mathrm{IU} / \mathrm{mL}, 58 \% / 42 \%$ had severe fibrosis/cirrhosis, $2 \%$ had genotype 1a, $14 \%$ were treatment naïve, $75 \%$ prior relapsers, $3 \%$ prior partial responders, $7 \%$ prior null responders and $1 \%$ had prior viral breakthrough. HCV RNA responses (percent undetectable) at weeks 4 and 12 (ITT analysis) are shown in Table 1.

\footnotetext{
* Correspondence: astreinucercel@yahoo.com

${ }^{1}$ Carol Davila University of Medicine and Pharmacy, Bucharest, Romania Full list of author information is available at the end of the article
}

Table 1

\begin{tabular}{llll}
\hline $\begin{array}{l}\text { Percent HCV RNA not } \\
\text { detected }\end{array}$ & $\begin{array}{l}\text { Week 4 } \\
\text { (RVR) }\end{array}$ & $\begin{array}{l}\text { Week 4+12 } \\
\text { (eRVR) }\end{array}$ & $\begin{array}{l}\text { Week } \\
\mathbf{1 2}\end{array}$ \\
\hline Treatment-naïve $(n=30)$ & $73 \%$ & $70 \%$ & $93 \%$ \\
Prior relapser $(n=156)$ & $85 \%$ & $81 \%$ & $94 \%$ \\
Prior partial responder $(n=6)$ & $100 \%$ & $83 \%$ & $83 \%$ \\
Prior null responder $(n=15)$ & $80 \%$ & $73 \%$ & $80 \%$ \\
Overall $^{a}(n=209)$ & $83 \%$ & $79 \%$ & $92 \%$ \\
\hline
\end{tabular}

ancludes 2 patients with prior virological break-through, not in four categories above

Nine patients (4\%) discontinued TVR due to adverse events, including six (3\%) for rash and one $(<1 \%)$ for anaemia. The rate of serious adverse events was $9 \%$ and no patients died during the study.

\section{Conclusion}

In this telaprevir early access program for hard-to-cure patients with severe fibrosis or compensated cirrhosis, early on-treatment virological responses are encouraging. Rates of discontinuation of telaprevir for adverse events were similar to Phase 3 trials.

\footnotetext{
Authors' details

${ }^{1}$ Carol Davila University of Medicine and Pharmacy, Bucharest, Romania. ${ }^{2}$ National Institute for Infectious Diseases "Prof.Dr. Matei Balş", Bucharest, Romania. " "Gr.T.Popa" University of Medicine and Pharmacy, laşi, Romania. ${ }^{4}$ Institute of Gastroenterology and Hepatology, "St Spiridon" Emergency Hospital, laşi, Romania. ${ }^{5}$ Victor Babeş University of Medicine and Pharmacy, Timişoara, Romania. ${ }^{6}$ Center for Digestive Diseases and Liver Transplantation, Fundeni Clinical Institute, Bucharest, Romania. ${ }^{7}$ Regional Institute of Gastroenterology and Hepatology, Cluj-Napoca, Romania. ${ }^{8}$ Janssen
} 
Published: 16 December 2013

doi:10.1186/1471-2334-13-S1-P58

Cite this article as: Streinu-Cercel et al:: Treatment of hepatitis $C$

genotype 1 patients with severe fibrosis or compensated cirrhosis: the

telaprevir early access program in patients from Romania. BMC Infectious

Diseases 2013 13(Suppl 1):P58.

Submit your next manuscript to BioMed Central and take full advantage of:

- Convenient online submission

- Thorough peer review

- No space constraints or color figure charges

- Immediate publication on acceptance

- Inclusion in PubMed, CAS, Scopus and Google Scholar

- Research which is freely available for redistribution

Submit your manuscript at 